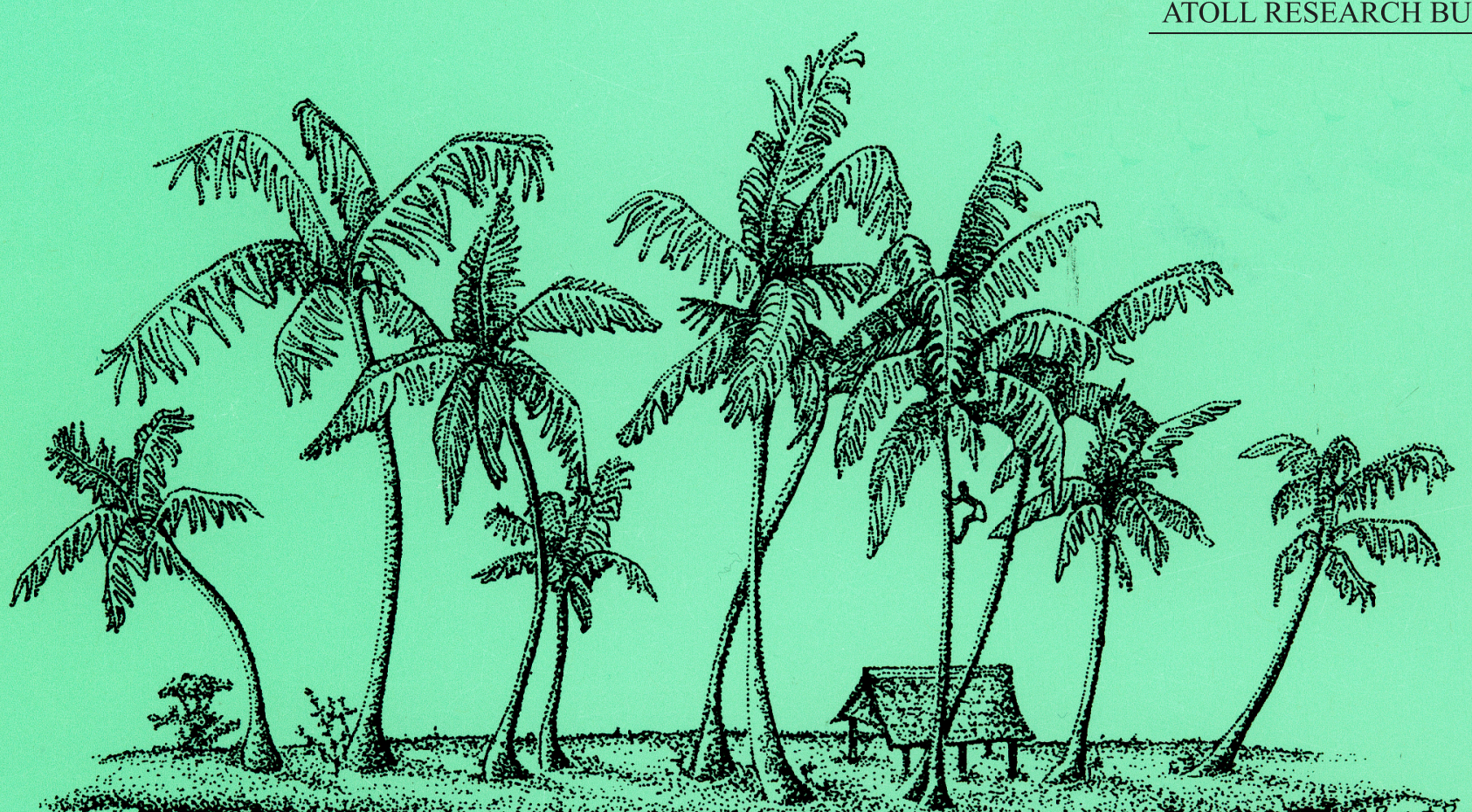

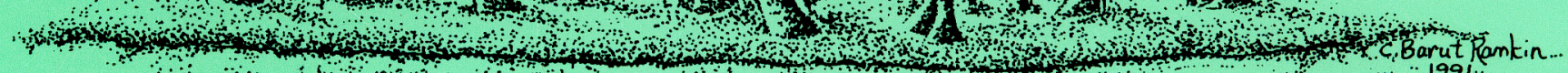

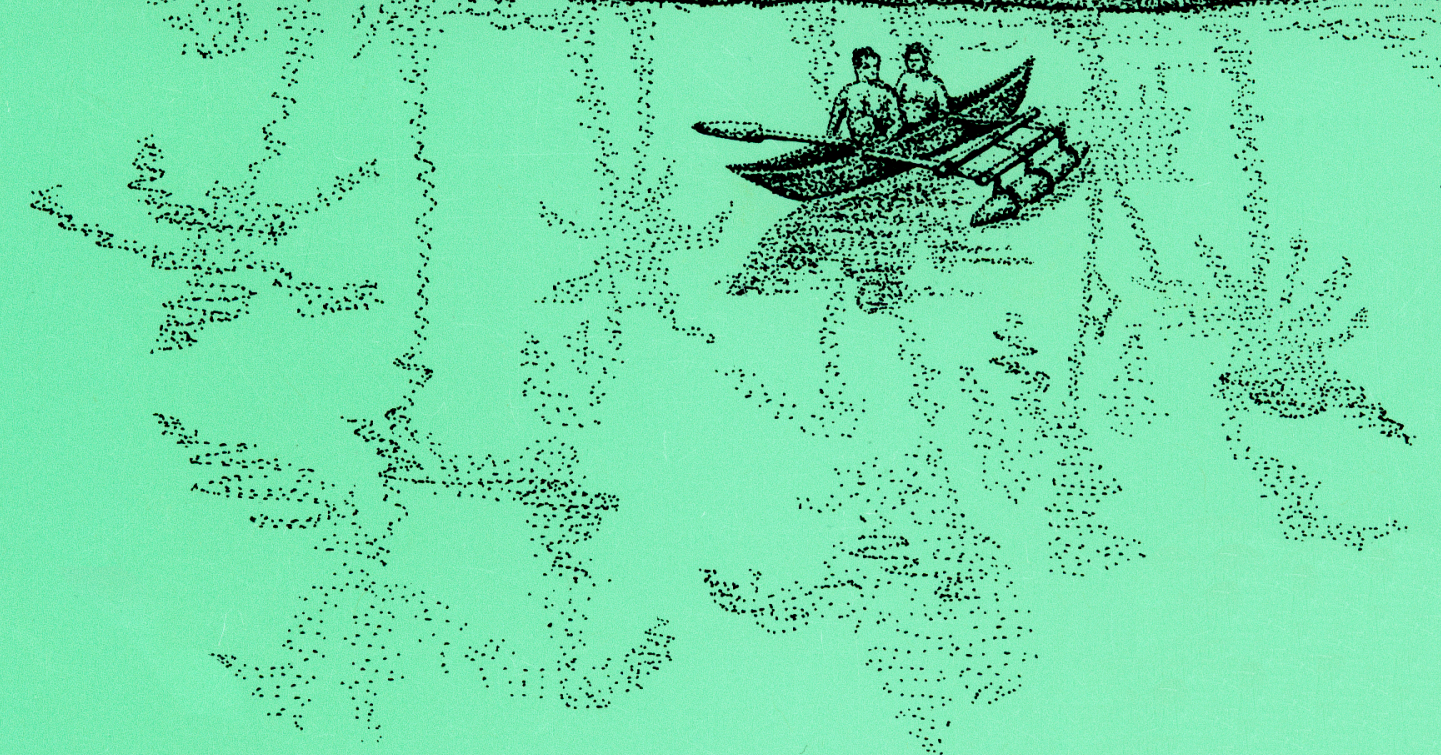

DIURON FROM MAUI SUGARCANE FIELD RUNOFF IS POTENTIALLY HARMFUL TO LOCAL CORAL REEFS

Thomas C. Royer, Patricia A. Tester, and Thomas N. Stewart

Smithsonian Institution Scholarly Press

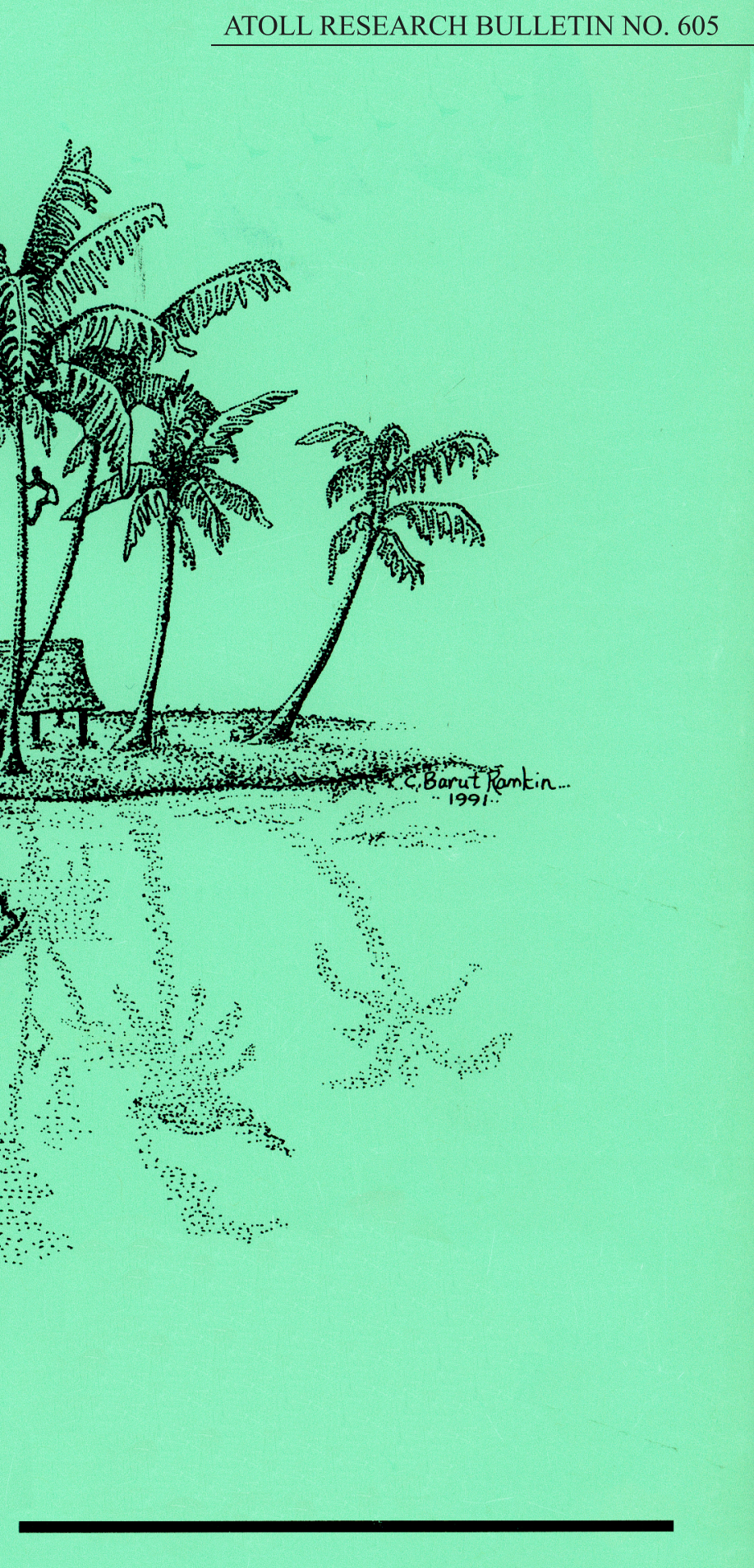

\section{ATOLL}

RESEARCH

BULLETIN 


\section{DIURON FROM MAUI SUGARCANE FIELD RUNOFF IS POTENTIALLY HARMFUL TO LOCAL CORAL REEFS}

Thomas C. Royer, Patricia A. Tester, and Thomas N. Stewart

Atoll Research Bulletin No. 605 8 October 2014

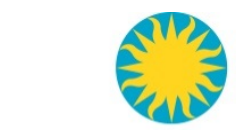

Smithsonian Institution Scholarly Press 
All statements made in papers published in the Atoll Research Bulletin are the sole responsibility of the authors and do not necessarily represent the views of the Smithsonian Institution or of the editors of the Bulletin. Articles submitted for publication in the Atoll Research Bulletin should be original papers and must be made available by authors for open access publication. Manuscripts should be consistent with the "Author Formatting Guidelines for Publication in the Atoll Research Bulletin." All submissions to the Bulletin are peer reviewed and, after revision, are evaluated prior to acceptance and publication through the publisher's open access portal, Open SI (http://opensi.si.edu).

Published by SMITHSONIAN INSTITUTION SCHOLARLY PRESS

P.O. Box 37012, MRC 957

Washington, D.C. 20013-7012

www.scholarlypress.si.edu

The rights to all text and images in this publication are owned either by the contributing authors or third parties. Fair use of materials is permitted for personal, educational, or noncommercial purposes. Users must cite author and source of content, must not alter or modify the content, and must comply with all other terms or restrictions that may be applicable. Users are responsible for securing permission from a rights holder for any other use.

ISSN: 0077-5630 (online) 


\title{
DIURON FROM MAUI SUGARCANE FIELD RUNOFF IS POTENTIALLY HARMFUL TO LOCAL CORAL REEFS
}

\author{
THOMAS C. ROYER ${ }^{1}$, PATRICIA A. TESTER ${ }^{2 *}$, and THOMAS N. STEWART ${ }^{3}$
}

\begin{abstract}
In a grassroots effort to identify stressors influencing the health of Maui's coral reefs, samples for the pre- and post-emergent herbicide, Diuron, were taken in July-August 2013, prior to, during, and after the passage of Tropical Storm Flossie on the south central coast of Maui, Hawaii. Diuron is routinely used on sugarcane fields adjacent to Hawaiian coastal waters and is a component of the anti-fouling paint used on small boats. It inhibits photosynthesis of terrestrial plants at concentrations as low as 0.1 parts per billion and can be lethal to endosymbiotic dinoflagellates in corals at concentrations less than 3 parts per billion, a concentration measured in runoff samples taken during this study. While Diuron was not detected in samples taken beyond the coastal outfall or in an adjacent boat basin, this effort provides evidence that a detectable influx of Diuron into Maui's coastal waters can result from a single rain event. Further, this study will inform efforts to support a ban on the use of Diuron in the wet season and guide monitoring efforts to better understand the effects of Diuron in coastal areas.
\end{abstract}

Keywords: Hawaii, endosymbiotic dinoflagellates, photosynthesis inhibitor, seasonal ban

\section{INTRODUCTION}

Diuron is registered by the U.S. Environmental Protection Agency (EPA) for pre- and post-emergent herbicide treatment of both crop and non-crop areas and is classified as a potential carcinogen. It is an effective herbicide used to control vegetation along rights of way areas adjacent roadways and canals and is also used on commercial crops like sugarcane to control weed growth. Diuron functions by directly inhibiting photosynthesis. It also kills a variety of aquatic organisms. Another source of Diuron in the marine environment is from the marine anti-fouling paint Duralux that is often used on small boats. This paint has, since the early 1990s, gradually replaced tributyltin as an anti-fouling agent.

Diuron is found in about $20 \%$ of U.S. rivers and streams according to the US Geological Survey and inhibits photosynthesis at concentrations as low as 0.1 parts per billion (ppb) (Cox, 2003). When introduced into aquatic environments via runoff, it also kills a variety of aquatic organisms. A recent study to connect upstream land use to water quality in Hawaii found Diuron in 14\% of sites tested in surface water at concentrations up to $0.07 \mathrm{ppb}$, well below the strictest benchmark concentrations of concern (2 ppb) (State of Hawaii Department of Health, 2014). Only a trace amount of Diuron was found at Kaanapali on the western coast of Maui; however, the sampling protocol did not account for seasonal precipitation patterns that make the timing of sampling for contaminants extremely important (State of

\footnotetext{
${ }^{1}$ Thomas C. Royer, Old Dominion University, 100 Hauoli Street, \# 412, Wailuku, HI 96793. TCRroyer@gmail.com

${ }^{2}$ Ocean Tester, LLC, 381 Gillikin Road, Beaufort, North Carolina, 28516. Ocean.Tester@gmail.com *Corresponding author

${ }^{3}$ Mercury Science Incorporated, 2801 Blue Ridge Road, Raleigh, NC 27607. Tom@MercuryScience.com
} 
Hawaii Department of Health, 2014). Recent concerns over the excessive use of agricultural chemicals led Kaua'i County, Hawaii, to pass strict laws (Ordinance 960, October 2013) requiring buffer zones and full pesticide application disclosure (http://qcode.us/codes/kauaicounty/revisions/960.pdf).

A seminal article by Jones et al. (2003) on Diuron describes its potential lethal effects on corals that depend on photosynthetic zooxanthellae. They conducted laboratory studies in Australia, exposing corals to varying concentrations of Diuron. A 10-hour exposure to a 3 ppb Diuron concentration caused death to about 35\% of the endosymbiotic dinoflagellates in Acropora formosa, Montipora digitata, Porites cylindrical and Seriatopora hystrix. This study and subsequent work eventually led to a ban in 2011 on the use of Diuron during the wet season on sugarcane fields that drain onto the Great Barrier Reef.

The coral coverage on Maui, Hawaii’s Maalaea Reef has declined from 50-75\% in 1993 to only 8\% in 2009 (Maui Coral Reef Recovery Team, 2012) and there is concern that herbicides and pesticides are in part responsible for poor coral reef health. The similarity of the conditions in Australia to those on Maui prompted an investigation of the presence of Diuron in the waters of Maalaea Bay, Hawaii, that receive runoff from sugarcane fields.

The Hawaiian Commercial and Sugar Company’s (HC\&S) website acknowledges the application of Diuron to sugarcane fields in Maui at least once during each growing season (http://mahaloindustriesllc.weebly.com/sugar-cane-operations.html). Additionally, this website notes, “Also, noxious weeds are controlled by applications of Roundup ${ }^{\circledR}$ in specific problem areas.” This is an ancillary weed control strategy using glyphosate (active ingredient in Roundup ${ }^{\circledR}$ ), which binds to aquatic sediments for up to a year (EPA, 1993; Solomon and Thompson, 2003). According to a report by Santo et al. (2000), $0.54 \mathrm{~kg}$ of Diuron per acre are applied annually on sugarcane fields in Hawaii. Maalaea Bay is adjacent to the HC\&S fields and those fields drain directly into it. This raised the question as to whether the presence of Diuron in Maalaea Bay could play a role in the reduction in corals there. This question was the focus of a 2013 study to test runoff from sugarcane fields into the near-shore waters of Maalaea Bay. The objective was to measure Diuron concentrations in runoff prior to, during, and after the passage of Tropical Storm Flossie in late July 2013.

\section{METHODS}

\section{Study Area}

Maalaea Bay is on the south central shore of a valley-like isthmus formed by erosional deposits from

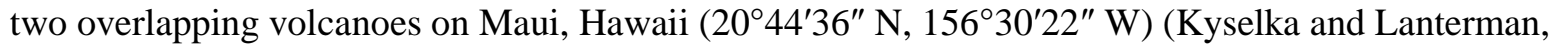
$1980)$. The older, northwestern volcano is Puu Kukui $(1,759 \mathrm{~m})$. Haleakala is to the southeast, rising to 2,000 m (Figure 1). Maui's climate is characterized by annual wet and dry seasons, dominant trade winds from the north-northeast and marked geographic differences in rainfall related to topography. Maalaea Bay is on the leeward side of Maui and somewhat shielded from the trade winds. It is in the rain shadow of the mountains and experiences dry conditions except for sporadic showers associated with ephemeral frontal systems. Maalaea Harbor is at the northwestern-most part of the bay and separated from the coastal water flow from the south by a breakwater. 


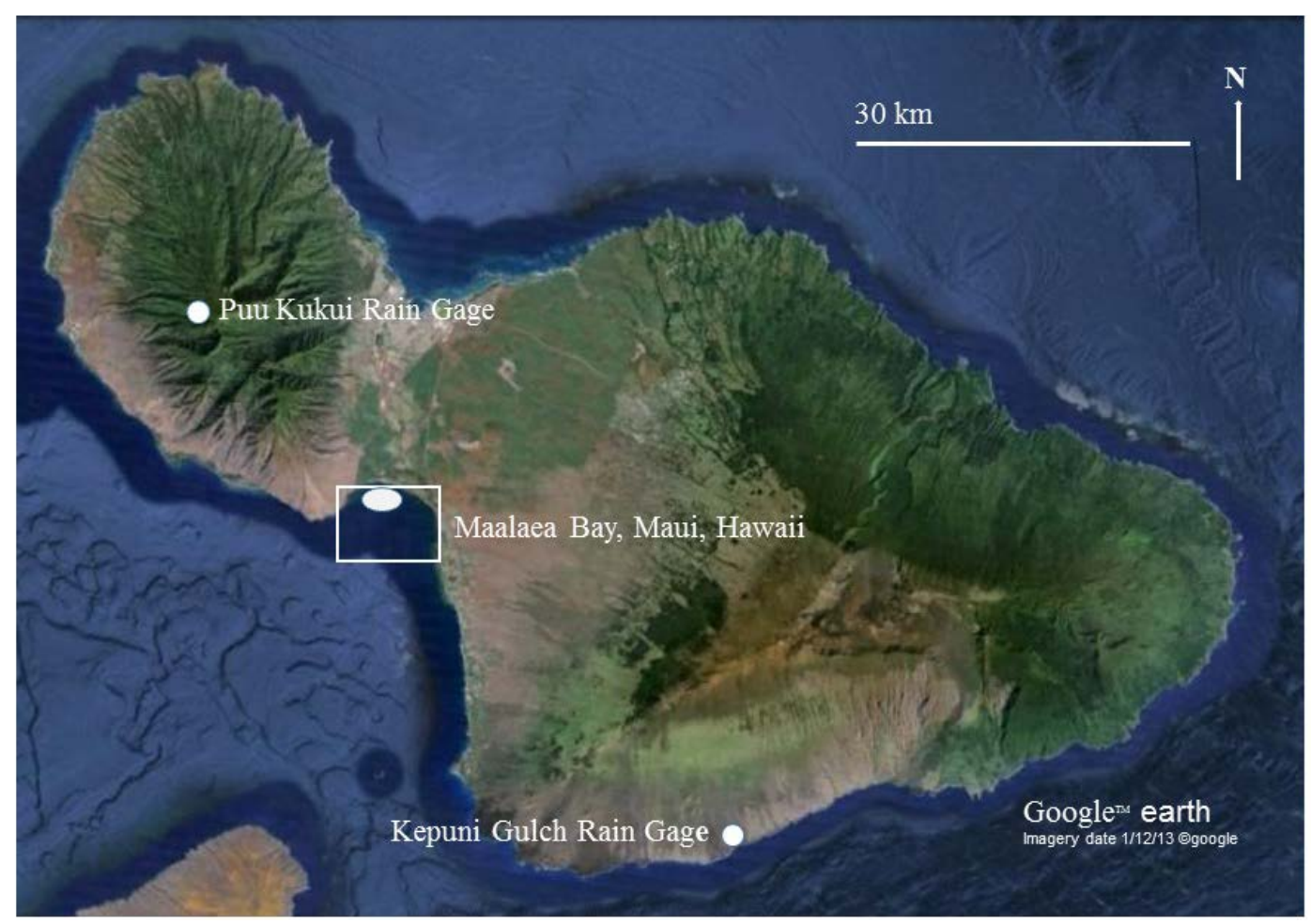

Figure 1. Maalaea Bay (square) and sampling site (oval), Maui, Hawaii, in relation to the local topography. The two rain gauges on Maui, Hawaii, are at Puu Kukui, Maui, Hawaii, in the north at 1,759 meters elevation and at Kepuni Gulch along the southwestern coast at 77.7 meters elevation (http://hi.water.usgs.gov/recent/hawaii). Data: LDEO-Columbia, NSF, NOAA, U.S. Navy, NGA, GEBCO. Image: Landsat. (C) 2014 Google.

\section{Sampling}

Water sampling took place before, during, and after the passage of Tropical Storm (TS) Flossie on July 29, 2013. It began on July 28 and ended six days later on August 3, 2013. Samples 1-2 and 4-7 were taken near the shore, from Island Sands Resort Condominium complex to Maalaea Harbor (Figure 2; Table 1) prior to TS Flossie. Sampling was repeated after TS Flossie (Samples 10-15). Samples 6, 7, 14 and 15 were taken on the northern side of the harbor. Samples 8 and 9 were drawn during TS Flossie from the runoff stream immediately east of Island Sands Resort Condominiums. Additional post-TS Flossie samples (16-17) were obtained on July 31 at Maalaea Harbor. Using a kayak on August 3, 2013, seven additional samples were gathered over the reef (Samples18-24). One blank sample (Sample 3, distilled water) was added to the group as a control, making 24 samples in all.

Surface samples were taken directly into $750 \mathrm{ml}$ amber glass bottles after each bottle was rinsed twice with ambient seawater. Subsurface samples were taken near bottom at depths from 1 to 4 meters using a Van Dorn bottle lowered on a calibrated line. Samples were stored at $4^{\circ} \mathrm{C}$ in the dark until they were shipped on cold packs to Mercury Science, Inc. (Raleigh, North Carolina) for analysis. 


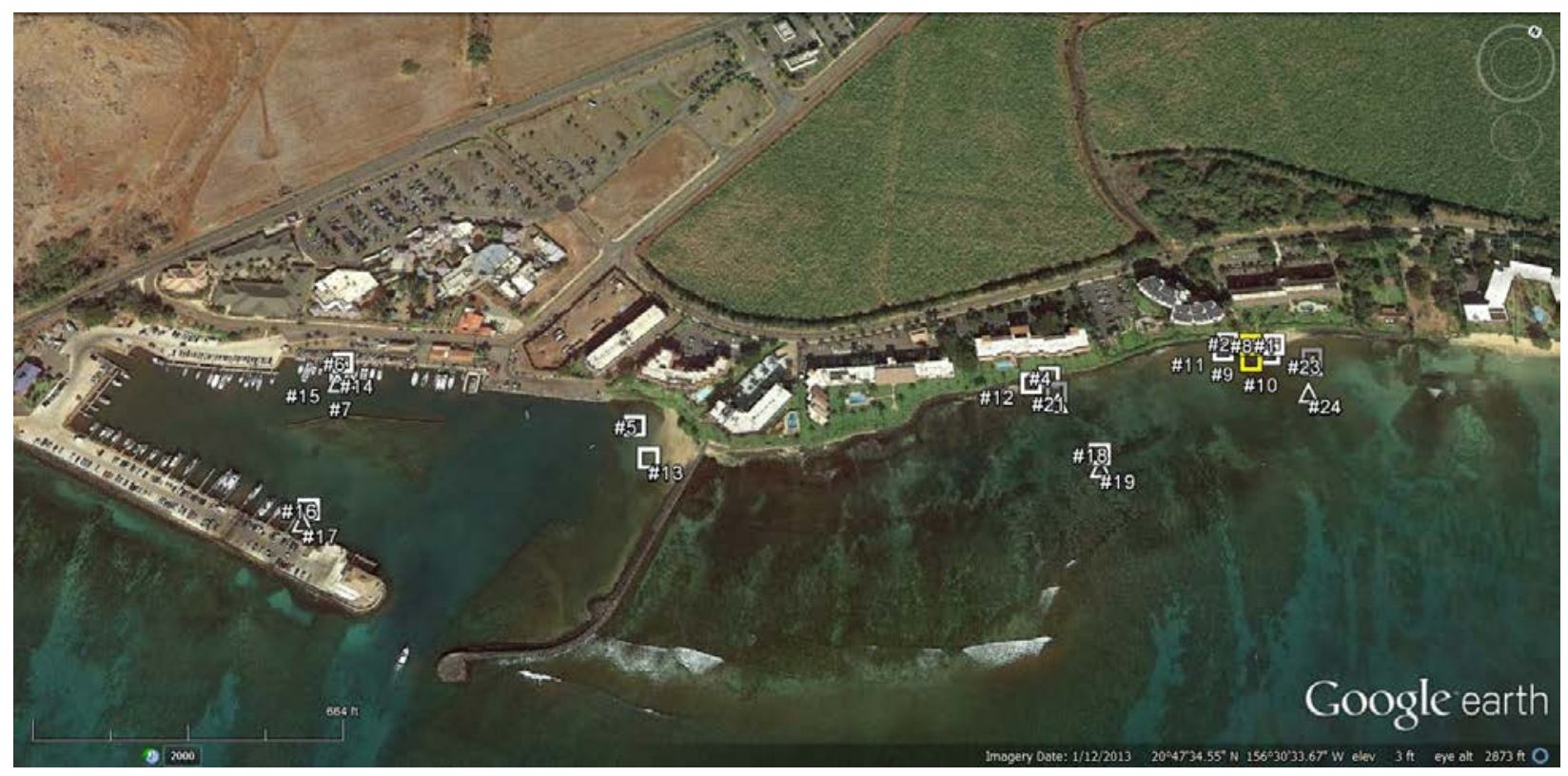

Figure 2. Sampling locations along Maalaea Bay, Maui, Hawaii. White squares indicate surface samples, white triangles indicate subsurface samples, and yellow squares mark stations that tested positive for Diuron in concentrations greater than 3 ppb (\#8 and \#9). (C) 2014 Google.

\section{Analytical Methods}

Samples were analyzed by immunoassay using the Diuron Plate Assay Kit manufactured by Abraxis (http://www.abraxiskits.com/productByCat.php?catId=47) (Celgene, Summit, NJ). Briefly, $50 \mu$ l aliquots of whole water samples and Diuron standard solutions were analyzed according to kit instructions. Samples were not concentrated or extracted. Samples were read using a Wallac Victor2 1420 Multilabel Counter (Perkin Elmer, Waltham, MA), at $450 \mathrm{~nm}$ wave length. Diuron concentrations were calculated using the calibration curve generated by a serial dilution of the standard included in the kit (Table 1) (Schneider et al., 1994). The detection limit of the test kit was 0.03 ppb Diuron. Samples containing less than $0.03 \mathrm{ppb}$ Diuron were categorized as non-detectable or below detection (BD).

\section{Precipitation}

Because of the importance of seasonal precipitation on the delivery and concentration of pollutants in runoff on Maui, the US Geological Survey's stream gauge database was examined. There are nine stream gauges on Maui but none on the western side of the island (http://waterwatch.usgs.gov/?m=real\&r=hi). However, there are two rain gauges, one located at the summit of Puu Kukui $\left(20^{\circ} 37^{\prime} 10.2^{\prime \prime} \mathrm{N}\right.$, $\left.156^{\circ} 15^{\prime} 06.8^{\prime \prime} \mathrm{W}\right)$ at 1,759 m elevation and the other at Kepuni Gulch $\left(20^{\circ} 37^{\prime} 10.2^{\prime \prime} \mathrm{N}, 156^{\circ} 15^{\prime} 06.8^{\prime \prime} \mathrm{W}\right)$ on the southwestern coast at $77.7 \mathrm{~m}$ elevation (http://hi.water.usgs.gov/recent/hawaii/puukukui.html) (see Figure 1). Of these two locations, the Kepuni Gulch rain gauge, at a lower altitude and on the coast, more closely reflects the precipitation pattern expected at the sampling site in Maalaea Bay. However, because of the importance of topography and the direction of approach of frontal systems, the Kepuni Gulch rain gauge is only an approximation of the conditions at Maalaea Bay. 
Table 1. Conditions and Diuron concentrations of water samples taken in Maalaea Bay, summer 2013. Samples 8 and 9 were positive for Diuron.

\begin{tabular}{|c|c|c|c|c|c|}
\hline Sample No. & $\begin{array}{l}\text { Date of } \\
\text { Sampling } \\
(2013)\end{array}$ & $\begin{array}{l}\text { Time of } \\
\text { Sampling } \\
\left(\text { HST }^{\mathrm{a}}\right)\end{array}$ & Location of Sample Site & $\begin{array}{l}\text { Sampling } \\
\text { Depth }\end{array}$ & $\begin{array}{l}\text { Diuron } \\
\text { Concentration } \\
\text { (ppb) }\end{array}$ \\
\hline 3 (Distilled Water) & $28 \mathrm{Jul}$ & 1522 & $\mathrm{n} / \mathrm{a}$ & $\mathrm{n} / \mathrm{a}$ & $\mathrm{BD}^{\mathrm{b}}$ \\
\hline \multicolumn{6}{|c|}{$\begin{array}{l}\text { Taken before } \\
\text { Tropical Storm Flossie }\end{array}$} \\
\hline 1 & $28 \mathrm{Jul}$ & 1550 & East of Island Sands outflow, $20^{\circ} 47.690^{\prime} \mathrm{N}, 156^{\circ} 30.395^{\prime} \mathrm{W}$ & Surface & $\mathrm{BD}$ \\
\hline 2 & $28 \mathrm{Jul}$ & 1555 & West of Island Sands outflow, $20^{\circ} 47.688^{\prime} \mathrm{N}, 56^{\circ} 30.399^{\prime} \mathrm{W}$ & Surface & $\mathrm{BD}$ \\
\hline 4 & $28 \mathrm{Jul}$ & 1610 & Lauloa steps, $20^{\circ} 47.639^{\prime} \mathrm{N}, 156^{\circ} 30.463^{\prime} \mathrm{W}$ & Surface & $\mathrm{BD}$ \\
\hline 5 & $28 \mathrm{Jul}$ & 1625 & Glass Beach, $20^{\circ} 47.537^{\prime} \mathrm{N}, 156^{\circ} 30.596^{\prime} \mathrm{W}$ & Surface & $\mathrm{BD}$ \\
\hline 6 & $28 \mathrm{Jul}$ & 1640 & Slip 65, Maalaea Harbor, $20^{\circ} 47.492^{\prime} \mathrm{N}, 156^{\circ} 30.735^{\prime} \mathrm{W}$ & Surface & $\mathrm{BD}$ \\
\hline 7 & $28 \mathrm{Jul}$ & 1645 & Slip 65, Maalaea Harbor, $20^{\circ} 47.492^{\prime} \mathrm{N}, 156^{\circ} 30.735^{\prime} \mathrm{W}$ & $1.75 \mathrm{~m}$ & $\mathrm{BD}$ \\
\hline
\end{tabular}

Taken during Tropical Storm Flossie,

2 hours after rain started

\begin{tabular}{|c|c|c|c|c|}
\hline & $29 \mathrm{Jul}$ & 1855 & Island Sands stream at water line, $20^{\circ} 47.696^{\prime} \mathrm{N}, 156^{\circ} 30.404^{\prime} \mathrm{W}$ & $\mathrm{n} / \mathrm{a}$ \\
\hline 9 & $29 \mathrm{Jul}$ & 1857 & Island Sands stream at water line, $20^{\circ} 47.696^{\prime} \mathrm{N}, 156^{\circ} 30.404^{\prime} \mathrm{W}$ & $\mathrm{n} / \mathrm{a}$ \\
\hline
\end{tabular}

Taken after

Tropical Storm Flossie

\begin{tabular}{|c|c|c|c|c|c|}
\hline 10 & $30 \mathrm{Jul}$ & 1600 & East of Island Sands outflow, $20^{\circ} 47.690^{\prime} \mathrm{N}, 156^{\circ} 30.395^{\prime} \mathrm{W}$ & Surface & $\mathrm{BD}$ \\
\hline 11 & $30 \mathrm{Jul}$ & 1605 & West of Island Sands outflow, $20^{\circ} 47.688^{\prime} \mathrm{N}, 156^{\circ} 30.399^{\prime} \mathrm{W}$ & Surface & $\mathrm{BD}$ \\
\hline 12 & $30 \mathrm{Jul}$ & 1610 & Lauloa steps, $20^{\circ} 47.639^{\prime} \mathrm{N}, 156^{\circ} 30.463^{\prime} \mathrm{W}$ & Surface & $\mathrm{BD}$ \\
\hline 13 & $30 \mathrm{Jul}$ & 1628 & Glass Beach, $20^{\circ} 47.537^{\prime} \mathrm{N}, 156^{\circ} 30.596^{\prime} \mathrm{W}$ & Surface & $\mathrm{BD}$ \\
\hline 14 & $30 \mathrm{Jul}$ & 1640 & Slip 65, Maalaea Harbor, $20^{\circ} 47.492^{\prime} \mathrm{N}, 156^{\circ} 30.735^{\prime} \mathrm{W}$ & Surface & $\mathrm{BD}$ \\
\hline 15 & $30 \mathrm{Jul}$ & 1645 & Slip 65, Maalaea Harbor, $20^{\circ} 47.492^{\prime} \mathrm{N}, 156^{\circ} 30.735^{\prime} \mathrm{W}$ & $1.75 \mathrm{~m}$ & $\mathrm{BD}$ \\
\hline 16 & $31 \mathrm{Jul}$ & 1614 & Slip 72, Maalaea Harbor ${ }^{\mathrm{c}}, 20^{\circ} 47.434^{\prime} \mathrm{N}, 156^{\circ} 30.703^{\prime} \mathrm{W}$ & Surface & $\mathrm{BD}$ \\
\hline 17 & $31 \mathrm{Jul}$ & 1618 & Slip 72, Maalaea Harbor ${ }^{\mathrm{c}}, 20^{\circ} 47.434^{\prime} \mathrm{N}, 156^{\circ} 30.703^{\prime} \mathrm{W}$ & $4 \mathrm{~m}$ & $\mathrm{BD}$ \\
\hline 18 & 3 Aug & 0945 & Lauloa steps line, outside station, $20^{\circ} 47.626^{\prime} \mathrm{N}, 156^{\circ} 30.444^{\prime} \mathrm{W}$ & Surface & $\mathrm{BD}$ \\
\hline 19 & 3 Aug & 0951 & Lauloa steps line, outside station, $20^{\circ} 47.626^{\prime} \mathrm{N}, 156^{\circ} 30.444^{\prime} \mathrm{W}$ & $1 \mathrm{~m}$ & $\mathrm{BD}$ \\
\hline 20 & 3 Aug & 1004 & Lauloa steps line, inner station, $20^{\circ} 47.634^{\prime} \mathrm{N}, 156^{\circ} 30.457^{\prime} \mathrm{W}$ & Surface & $\mathrm{BD}$ \\
\hline 21 & 3 Aug & 1011 & Lauloa steps line, inner station, $20^{\circ} 47.634^{\prime} \mathrm{N}, 156^{\circ} 30.457^{\prime} \mathrm{W}$ & $1.5 \mathrm{~m}$ & $\mathrm{BD}$ \\
\hline 22 & 3 Aug & 1035 & East line of stream, $20^{\circ} 47.692^{\prime} \mathrm{N}, 156^{\circ} 30.359^{\prime} \mathrm{W}$ & Surface & $\mathrm{BD}$ \\
\hline 23 & 3 Aug & 1041 & East line of stream, $20^{\circ} 47.692^{\prime} \mathrm{N}, 156^{\circ} 30.359^{\prime} \mathrm{W}$ & $2 \mathrm{~m}$ & $\mathrm{BD}$ \\
\hline 24 & 3 Aug & 1053 & Off stream, $20^{\circ} 47.666^{\prime} \mathrm{N}, 156^{\circ} 30.380^{\prime} \mathrm{W}$ & $2 \mathrm{~m}$ & $\mathrm{BD}$ \\
\hline
\end{tabular}

\footnotetext{
${ }^{a}$ Hawaii Standard Time

${ }^{\mathrm{b}}$ Below detection $(<0.03 \mathrm{ppb})$

${ }^{\mathrm{c}}$ Winds at 25-30 knots
} 


\section{RESULTS}

\section{Diuron Analysis}

Twenty-two of the 24 samples (Table 1 ) had no detectable Diuron concentrations (<0.03 ppb). Twenty-one samples were obtained adjacent to and over the reef. One sample (Sample 3) was a distilled water blank. Two of the 24 samples had concentrations of >3 ppb (3.4 ppb, Sample 8; 3.3 ppb, Sample 9) (Table 1). Those samples were obtained from the stream on the eastern side of the Island Sands Resort Condominium complex on 29 July 2013 (Figure 2). The stream, which contained runoff from TS Flossie, was sampled approximately 2 hours (1855 Hawaiian Standard Time [HST]) after the rains began while the stream was flowing. Three hours later (2200 HST) the stream was no longer flowing. No elevated Diuron concentrations were recorded for the samples taken in the Maalaea Harbor boat basin before or after the passage of TS Flossie.

\section{Precipitation}

Rainfall averages more than $980 \mathrm{~cm}$ per year at the higher elevations of Puu Kukui (Figure 3) while during the same period Kepuni Gulch has an average of only $30-31 \mathrm{~cm}$ of precipitation (Figure 4) (http://www.prh.noaa.gov/hnl/hydro/pages/maui_05.gif; http://waterdata.usgs.gov/hi/nwis/). We note the relatively few rainfall occurrences of $5 \mathrm{~cm}$ or greater at Kepuni Gulch throughout the eight-year record (Figure 4), and observe there were no rainfall events with precipitation totals of $5 \mathrm{~cm}$ during the period between 2010 and 2012, a time of extremely dry conditions. Tropical Storm Flossie's rainfall measured $10 \mathrm{~cm}$ on 29 July 2013 and about $7 \mathrm{~cm}$ the following day, making this a major runoff event for Maalaea Bay. In contrast, rainfall events at Puu Kukui seem to average 12-13 cm and commonly exceed $25 \mathrm{~cm}$ (Figure 3). Unfortunately, the rain gauge at Puu Kukui was not operational during the passage of TS Flossie in late July 2013 for comparative measurements between the two rain gauges.

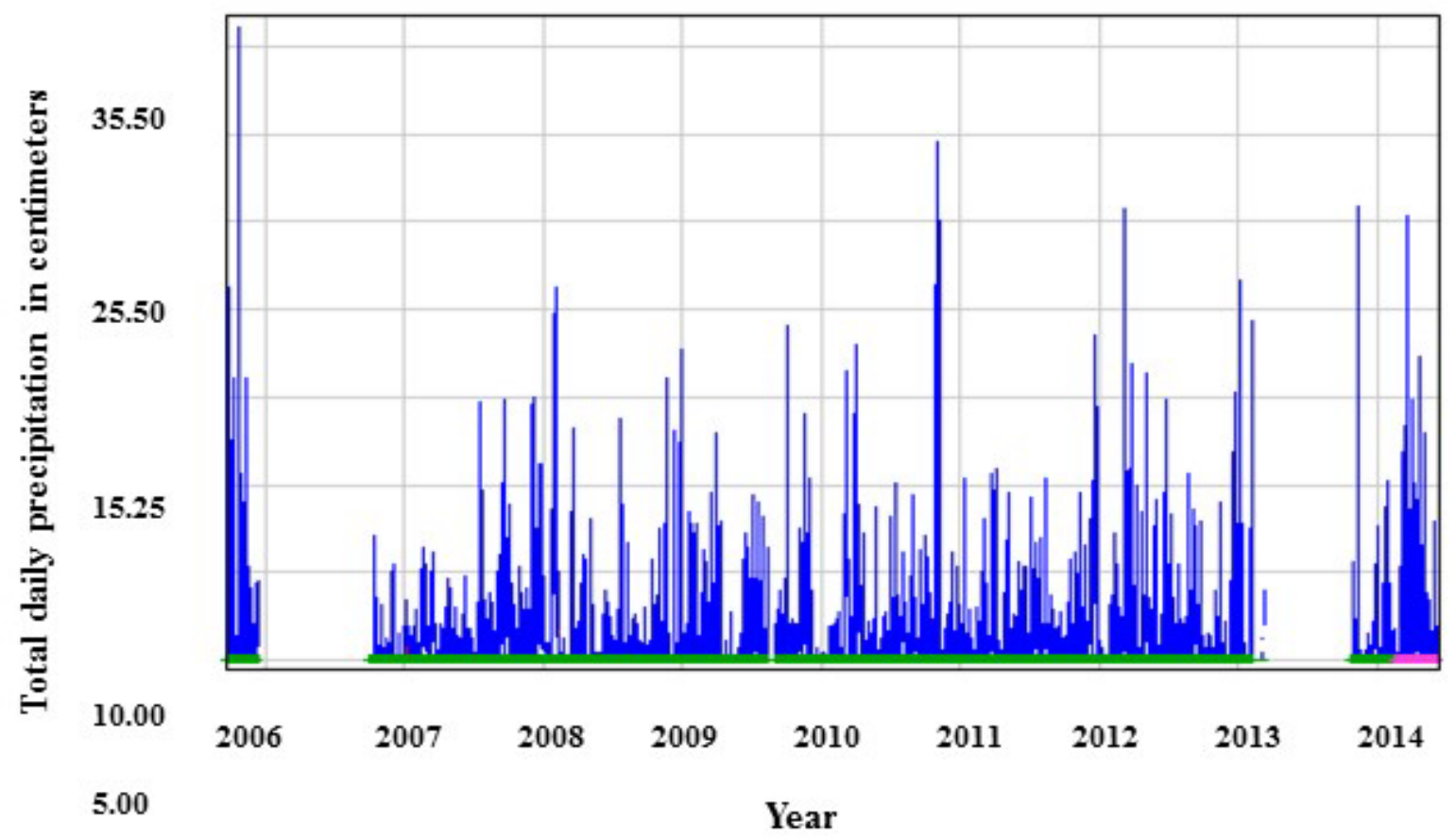

Figure 3. Daily precipitation total in centimeters at the US Geological Service rain gage at Puu Kukui, Maui, Hawaii, from 2006 to April 2014. USGS rain gauge 205327156351102380.0 is located 1,759 meters above sea level in north-central Maui, Hawaii (http://waterdata.usgs.gov/hi/nwis/). 


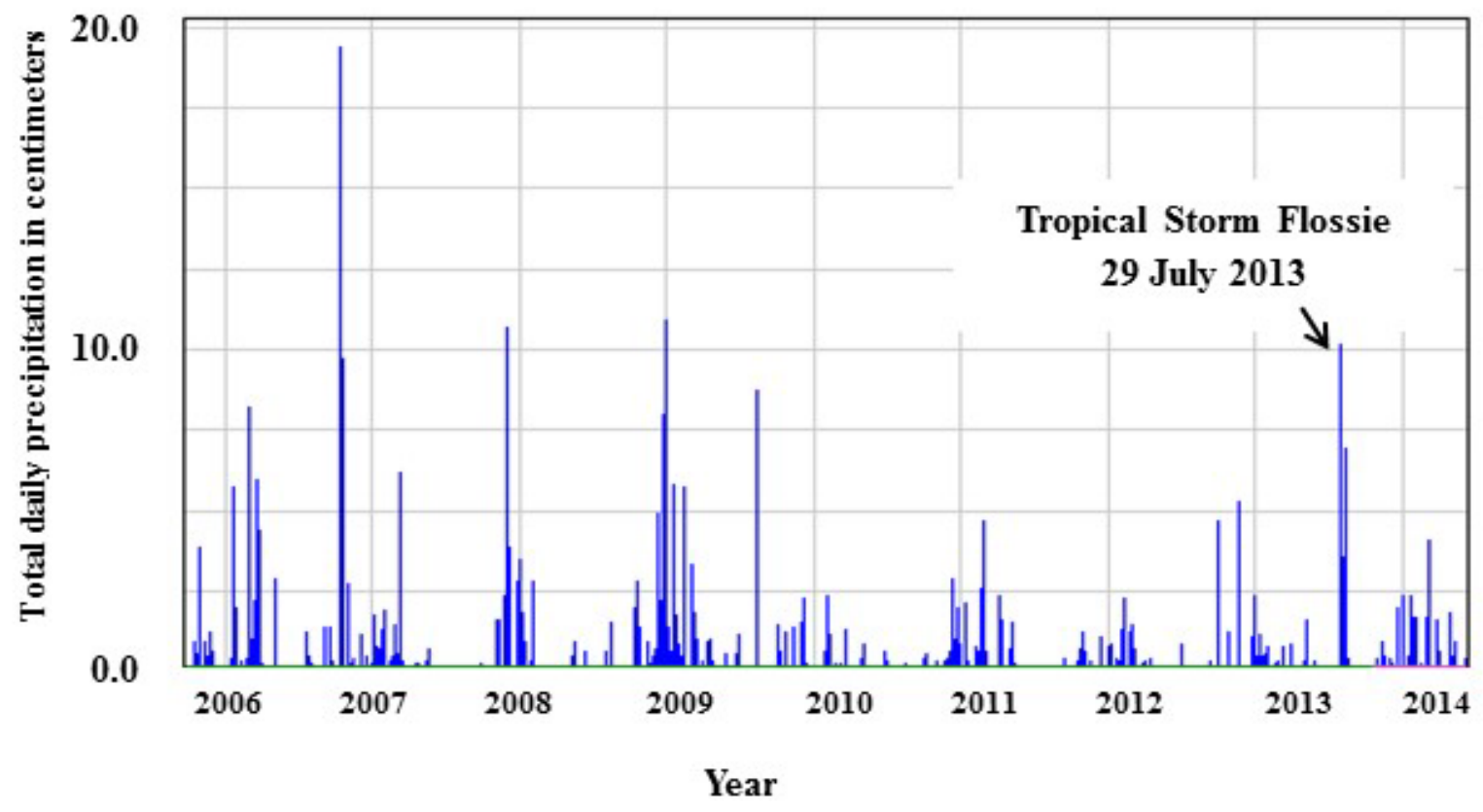

Figure 4. Daily precipitation total in centimeters at the US Geological Service rain gauge at Kepuni Gulch, Maui, Hawaii from 2006 to April 2014. USGS rain gauge 203721156151601 is located 77.7 meters above sea level on the southwestern coast of Maui (http://waterdata.usgs.gov/hi/nwis/).

\section{DISCUSSION}

Runoff from the $1.39 \mathrm{~km}^{2}$ HC\&S sugarcane field in Maalaea, Maui, contained concentrations of Diuron ( $>3 \mathrm{ppb})$. This concentration of Diuron is significant in that it has the potential to be lethal to corals. Laboratory studies completed in Australia by Jones et al. (2003) show that concentrations of Diuron similar to those found in the Maalaea runoff killed about 35\% of the corals within 10 hours. The relatively minor runoff from TS Flossie was diluted as it entered the ocean and Diuron was not detectable away from the outfall. During TS Flossie, only a trace of rain was recorded at Kahului Airport (http://cdo.ncdc.noaa.gov/qclcd/QCLCD), about $15 \mathrm{~km}$ north of Maalaea Bay. Summer is generally the dry season on Maui, with higher precipitation in winter. An extreme example of seasonal rainfall occurred on 13-14 January, 2011, when $7.0 \mathrm{~cm}$ of rainfall was recorded (http://cdo.ncdc.noaa.gov/qclcd/QCLCD) at the Kahului Airport, although this event was not recorded by the Kepuni Gulch rain gage $60 \mathrm{~km}$ to the south. For the July 2013 rain event, the stream flow lasted only several hours; after the January 2011 storm, the outfall stream continued to flow for several days (personal observation, T. Royer). Thus, extreme rain events have the potential to inject high volumes of runoff with potentially high concentrations of Diuron or other herbicides and pesticides directly onto the reef. Further, the accumulation of Diuron in sediments associated with runoff events and subsequent release into the food web is a consideration as well. Its half-life is reported to be on the order of hundreds of days (Australian Pesticides and Veterinary Medicines Authority, 2011).

The State of Hawaii has no ongoing stream monitoring program for pesticides, and there is little information for evaluation of current pesticide use practices resulting in off-site movement into state waters. Data from the State of Hawaii Department of Health draft report (2014) provide preliminary information on the presence /absence of pesticide residue levels in surface waters and support one of the Maui Coral Reef Recovery Team's (2012) highest priorities for direct restoration of Maui’s reef ecosystems, reduction sedimentation and runoff. Because of the recent awareness heightened by the Maui 
Coral Reef Recovery Team's report (2012) and the State of Hawaii Department of Health's draft report (2014) on pesticides and water quality, plans are underway to develop a catchment basin for the runoff from the stream draining the sugarcane field adjacent to Maalaea Bay. This is a step in the right direction and in concert with the Coral Reef Recovery Team's goal of identifying key stressors to Maui's coral reefs. Another step toward this goal would be the Hawaiian Commercial and Sugar Company (HC\&S) agreement to halt the use of Diuron on its sugarcane fields until more extensive studies of the effects of Diuron on Maui's corals can be carried out. Further, HC\&S should not replace Diuron with other herbicides, such as Roundup ${ }^{\circledR}$, until they have been proven safe for use in areas adjacent to coral reef ecosystems.

It is not known if Maui's coral population of Montipora spp. or Pocillopora spp. (Brown, 2008) is more or less sensitive to Diuron than the corals found on the Great Barrier Reef in Australia; however, the fragile condition of the reef dictates immediate relief from any factors that might be affecting its health.

Future studies should include routine monitoring for Diuron, as well as other herbicides and pesticides, in the runoff and over the reef, and the responses of local corals. This sampling should take into account the seasonal rainfall pattern along the southern Maui coast and the sporadic nature of the runoff.

\section{ACKNOWLEDGMENTS}

This study was funded by the Surfrider Foundation, Sierra Club, Maui Tomorrow, and the Maalaea Community Association. Their support and encouragement are gratefully acknowledged. Randolph L. Hartshorn assisted in the sample collection and his efforts are greatly appreciated.

\section{REFERENCES}

Australian Pesticides and Veterinary Medicines Authority. 2011. Diuron Environmental Assessment. Canberra: Australian Government.

Brown, E. 2008. Coral community structure and recent trends along the west Maui coastline. In Coral Reefs of Maui: Status, Stressors and Suggestions, ed. M. Vermeij, pp. 33-35. Selfpublished. http://www.hawaii.edu/kahekili/MauiReefs.pdf

Cox, C. 2003. Herbicide fact sheet diuron. Journal of Pesticide Reform, 23:12-20.

Environmental Protection Agency. 1993. Registration Decision Fact Sheet for Glyphosate. R.E.D. FACTS. Washington, D.C.: United States Environmental Protection Agency.

Jones, R. J., J. Muller, D. Haynes, and U. Schreiber. 2003. Effects Of Herbicides Diuron and Atrazine on Corals of the Great Barrier Reef, Australia. Marine Ecology Progress Series, 251:153-167.

Kyselka, W., and R. E. Lanterman. 1980. Maui: How It Came to Be. Honolulu: University of Hawaii Press.

Maui Coral Reef Recovery Team. 2012. Ola nā Papa i Mālama 'ia: A Practical Plan for the Technical and Cultural Restoration of Maui’s Coral Reefs. Kihei: Maui Nui Marine Resource Council.

Santo, L. T., S. Schenck, H. Chen and R. V. Osgood. 2000. Crop Profile for Sugarcane in Hawaii. Honolulu: Hawaii Agriculture Research Center. http://www.ipmcenters.org/cropprofiles/docs/hisugarcane.html.

Schneider, P. M. H. Goodrow, S. J. Gee, B. D. Hammock. 1994. A Highly Sensitive and Rapid ELISA for the Arylurea Herbicides Diuron, Monuron and Linuron. Journal of Agricultural and Food Chemistry, 42: 413-422.

Solomon, K. R., Thompson, D. G. 2003. Ecological Risk Assessment for Aquatic Organisms from Over Use of Glyphosate. Journal of Toxicology and Environmental Health Part B Critical Reviews, 6: 289-324. doi:10.1080/10937400306468.PMID 12746143.

State of Hawaii Department of Health. 2014. 2013-2014 State Wide Pesticide Sampling Pilot Project Water Quality Findings. Draft Report. Honolulu: State of Hawaii. http://ehaweb.doh.hawaii.gov/eha-cma/Leaders/HEER/statewide-pesticide-survey. 